\title{
OPTICAL MODELING AND SIMULATION OF TANDEM METAL OXIDE SOLAR CELLS
}

\author{
Florin Drăgan ${ }^{1}, \emptyset_{\text {rnulf Nordseth }}^{2}$, Laurențiu Fara ${ }^{1,3,{ }^{*}}$, Constantin Dumitru ${ }^{1}$, Dan \\ Crăciunescu $^{1}$, Vlad Muscurel ${ }^{1}$, Paul Sterian ${ }^{1,3}$ \\ ${ }^{1}$ University "Politehnica” of Bucharest, Spl. Independentei 313, RO-060042, Bucharest, Romania \\ ${ }^{2}$ Institute for Energy Technology, Instituttveien 18, NO-2007 Kjeller, Norway \\ ${ }^{3}$ Academy of Romanian Scientists, Spl. Independentei 54, RO-030167, Bucharest, Romania \\ *Corresponding author: lfara@renerg.pub.ro
}

\begin{tabular}{|c|c|}
\hline Article Info & Abstract \\
\hline $\begin{array}{l}\text { Received: } 02.03 .2018 \\
\text { Accepted: } 15.06 .2018 \\
\text { Keywords: } \\
\text { tandem solar cells, metal } \\
\text { oxides, cuprous oxide, } \\
\text { zinc oxide, optical } \\
\text { modeling, ray tracing, } \\
\text { transfer matrix, absorber } \\
\text { layer, buffer layer. }\end{array}$ & 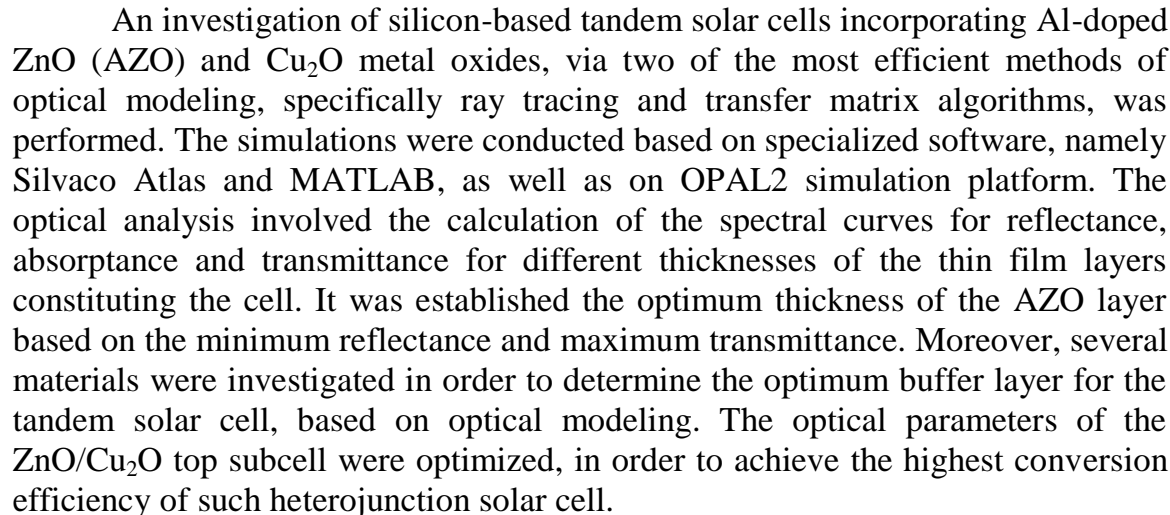 \\
\hline
\end{tabular}

\section{Introduction. State of the art}

Progress in the design of thin film solar cells has accelerated the development of tandem solar cells based on crystalline silicon (c-Si) that yield better conversion efficiencies compared to the c-Si single-junction implementation. Such improvements are required in order to ensure competitiveness versus conventional energy sources $[1,2]$. Recently, tandem solar cells have been implemented on III-V type semiconductors, monocrystalline, polycrystalline, and amorphous silicon, dye sensitized solar cells, and quantum dot solar cells. The commercial manufacturing of silicon based tandem heterojunction solar cells (STHSC) with high efficiency and low cost has not been achieved yet. A promising material 
for a STHSC implementation is cuprous oxide $\left(\mathrm{Cu}_{2} \mathrm{O}\right)[3,4,5]$. This semiconducting metal oxide has a high optical absorption, is non-toxic, and has the potential for low production cost $[6,7,8]$. The theoretical limit of the conversion efficiency for a solar cell based on $\mathrm{Cu}_{2} \mathrm{O}$ is close to $20 \%$ under one sun illumination. However, the literature reports that the highest conversion efficiency achieved experimentally is $8.1 \%$ for a $\mathrm{ZnO} / \mathrm{Cu}_{2} \mathrm{O}$ solar cell based on thermally oxidized copper sheets, suggesting that further research of $\mathrm{Cu}_{2} \mathrm{O}$-based solar cells is still needed in order to optimize them for photovoltaic applications.

Figure 1 shows a schematic design of a STHSC, that combines a conventional crystalline silicon bottom subcell with a $\mathrm{ZnO} / \mathrm{Cu}_{2} \mathrm{O}$ top subcell in a mechanical stack of independently connected cells, i.e . a four-terminal configuration. The high band gap of $\mathrm{Cu}_{2} \mathrm{O}$ $\left(E_{g}=2.1 \mathrm{eV}\right)$, which is approximately $1 \mathrm{eV}$ higher than that of crystalline silicon $\left(\mathrm{E}_{\mathrm{g}}=1.13\right.$ $\mathrm{eV}$ ), would yield a less efficient low-cost two-terminal tandem configuration. A four-terminal configuration allows for accessing a wider range of material combinations compared to a two-terminal configuration since there is a constraint on current matching for the two subcells $[1,9]$.

For the top subcell, a heterojunction between cuprous oxide and a buffer layer (n-type) is being used. Numerical modeling shows that an optimal material implementation for the buffer layer is very important for the electronic and optical performance of the heterojunction [10].

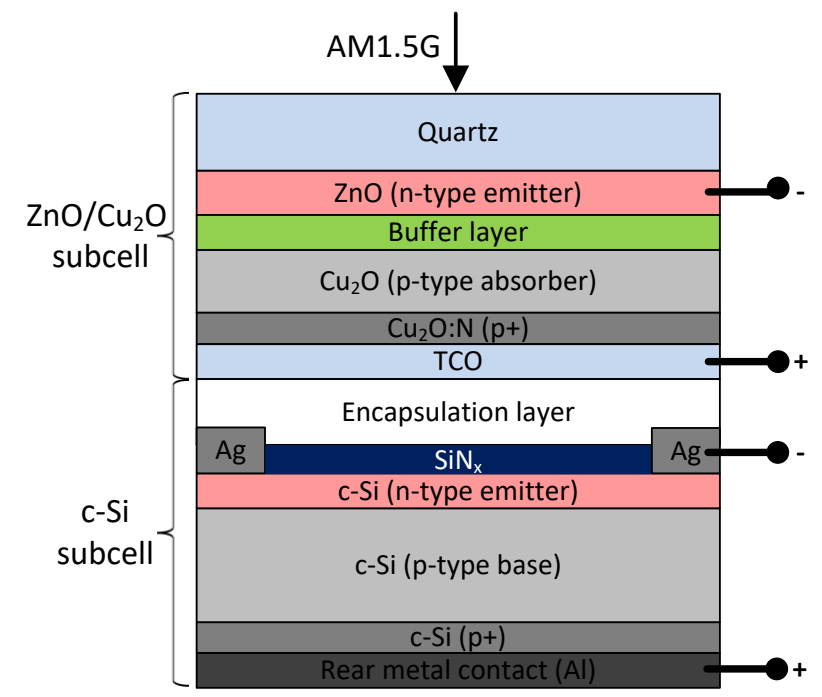

Fig. 1. Schematic of the four-terminal tandem metal oxide solar cell [9]

This paper presents a review of different optical modeling and numerical simulation studies of the STHSC, recently published by the authors. The optical analysis involves ray tracing method to calculate the spectral curves for reflectance, absorptance, and transmittance 
for different thicknesses of the thin film layers of the $\mathrm{ZnO} / \mathrm{Cu}_{2} \mathrm{O}$ subcell. Such approach can provide useful information for the layer optimization, in order to ensure efficient light management in the solar cell.

\section{Methods of optical modeling for advanced solar cells}

\subsection{Main methods for optical modeling}

Using Technology Computer-Aided Design (TCAD) simulation software, such as Silvaco Atlas [11], the propagation of light can be described by any of the four physical models or several user defined approaches. The physical models for light propagation include the following:

- Ray tracing (RT) is a general method of resolving 2D and 3D non-planar geometries but ignores coherence and diffraction effects.

- The transfer matrix method (TM) is a 1D method that includes interference effects. This method is recommended for large area devices such as thin film solar cells.

- The beam propagation method (BP) is a general 2D method that includes diffraction effects at an increased computational expense.

- Finite difference time domain (FDTD) is the most general 2D and 3D method and accounts for both diffraction and coherence by direct solution of Maxwell's equations. This is the most computationally expensive approach.

This review article is based only on two methods, respectively ray tracing (RT) and transfer matrix (TM).

\subsection{Ray tracing method}

Optoelectronic device simulation is split into two distinct models that are calculated simultaneously at each DC bias point or transient timestep:

1. Optical ray trace using real component of refractive index to calculate the optical intensity at each grid point;

2. Absorption or photogeneration model using the imaginary component of refractive index to calculate a new carrier concentration at each grid point.

\section{Ray tracing in $2 D$}

An incident optical beam is modeled as a collimated source. As shown in Figure 2a, the illumination window is "clipped" against the device domain so that none of the beam bypasses the device. The beam is automatically split into a series of rays so that the sum of 
the rays covers the entire width of the illumination window. When the beam is split, the software automatically resolves discontinuities along the region boundaries of the device.
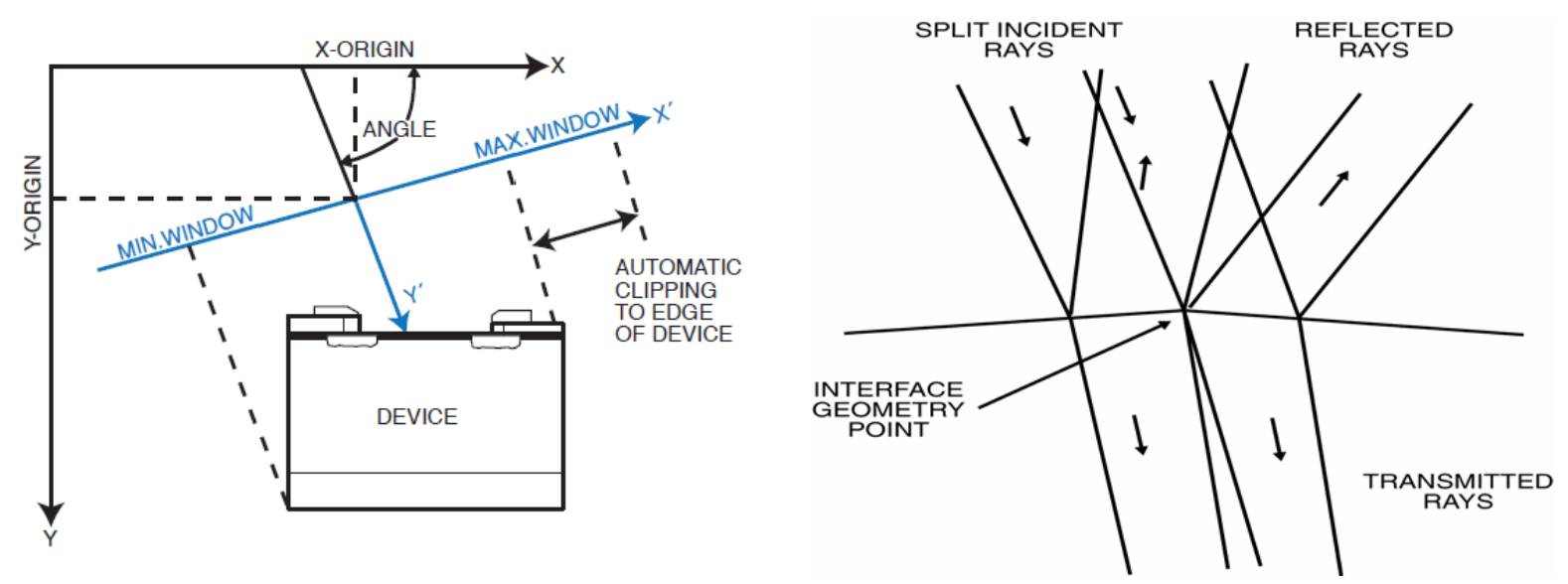

Fig. 2. a) Optical beam geometry; b) Reflected and transmitted rays [11].

Rays are also split at interfaces between regions into a transmitted ray and a reflected ray. Figure $2 b$ illustrates the difference between rays that are split to resolve the geometry and transmitted / reflected rays split at a region interfaces.

\section{Ray tracing in $3 D$}

In $3 \mathrm{D}$, the algorithm doesn't automatically split rays to resolve topological features of the device. The 3D source geometry is very similar to the geometry shown in Figure 2a. In $3 \mathrm{D}$, the source origin is specified by three coordinates for the origin of beam: $\mathrm{X}, \mathrm{Y}$, and $\mathrm{Z}$. Unlike Figure 2a, there are two angles that describe the direction of propagation. As can be seen in Figure 3, the angle PHI describes is the angle or propagation with respect to the XZ plane. The angle THETA describes the angle of rotation specified about the Y axis.

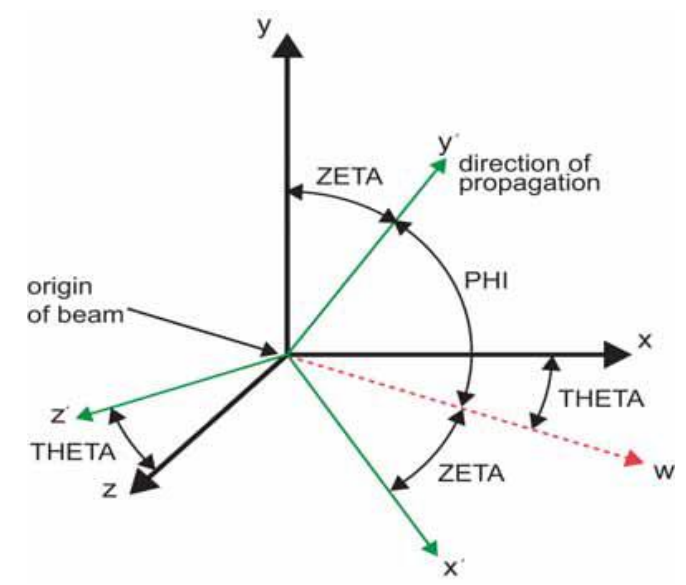

Fig. 3. Propagation in 3D [11]. 


\subsection{Transfer matrix method}

The Transfer Matrix (TM) method allows for a fast and accurate way to simulate electromagnetic wave propagation through a layered medium. In the matrix theory, the characteristic matrix and the transfer matrix descriptions are commonly used [11].

The structure of a multilayer stack completely determines its characteristic matrix. The transfer matrix also contains information about the media on both sides of the layer stack. The characteristic matrix approach is considered to be more general and can be expanded to include graded interfaces, in which instance, the transfer matrix method is inappropriate to implement.

The characteristic matrix of a multilayer is basically a product of corresponding single layer matrices. If $\mathrm{m}$ is the number of layers, then the field at the first $\left(\mathrm{z}=\mathrm{z}_{0}\right)$ and the last $\left(\mathrm{z}=\mathrm{Z}_{\mathrm{m}}\right)$ boundaries are related as seen in the equation below:

$$
\left[\begin{array}{l}
E\left(Z_{0}\right) \\
H\left(Z_{0}\right)
\end{array}\right]=M_{1}, M_{2} \ldots M_{m}\left[\begin{array}{l}
E\left(Z_{m}\right) \\
H\left(Z_{m}\right)
\end{array}\right], M_{i}=\left[\begin{array}{cc}
\cos \varphi_{i} & j \sin \varphi_{i} / Y_{i} \\
j Y_{i} \sin \varphi_{i} & \cos \varphi_{i}
\end{array}\right]
$$

The derivation of amplitude reflection ( $\mathrm{r}$ ) and transmission $(\mathrm{t})$ coefficients is resulting in the following expressions:

$$
\begin{aligned}
& r=\frac{Y_{0} M_{11}+Y_{0} Y_{S} M_{12}+M_{21}-Y_{S} M_{22}}{Y_{0} M_{11}+Y_{0} Y_{S} M_{12}+M_{21}+Y_{S} M_{22}} \\
& t=\frac{2 Y_{0}}{Y_{0} M_{11}+Y_{0} Y_{S} M_{12}+M_{21}+Y_{S} M_{22}}
\end{aligned}
$$

where $Y_{0}$ and $Y_{s}$ are the characteristic admittances of the media on both sides of the multilayer. $\mathrm{M}_{\mathrm{ij}}$ are the elements of the characteristic matrix of the multilayer. Light is incident from the medium with admittance $\mathrm{Y}_{0}$. The energy coefficients (reflectance, transmittance, and absorptance) are given as:

$$
\begin{gathered}
R=|r|^{2} \\
T=\frac{\operatorname{Re}\left(Y_{S}\right)}{\operatorname{Re}\left(Y_{0}\right)}|t|^{2} \\
A=(1-R)\left[1-\frac{\operatorname{Re}\left(Y_{S}\right)}{\operatorname{Re}\left[\left(M_{11}+Y_{S} M_{12}\right)\left(M_{21}+Y_{S} M_{22}\right)^{*}\right]}\right]
\end{gathered}
$$

\section{Simulation tools}

This review article on tandem solar cells based on metal oxides and crystalline silicon considered the following simulation software tools: Silvaco, OPAL2 and MATLAB for 
optical modeling approach. These tools allowed to obtain useful results concerning optimization of the STHSC under investigation, as follows:

- OPAL2 simulation platform was used for evaluation of optical spectral characteristics, respectively reflectance, absorptance, and transmittance for different component layers of the STHSC.

- MATLAB software allowed the implementation of transfer matrix algorithm in order to analyze possible buffer layer materials for the STHSC from an optical point of view.

- Silvaco software contributed to the evaluation of dependence of photo-generated current on thickness of the absorber layer $\left(\mathrm{Cu}_{2} \mathrm{O}\right)$ in order to establish the optimum thickness of such layer specific for the STHSC.

\section{Results and Discussions}

In the STHSC structure, the thermal losses are lowered if most high energy photons are absorbed in the top subcell, and therefore it is advantageous to absorb most of the high energy photons in the $\mathrm{Cu}_{2} \mathrm{O}$ absorber layer. Figure 4(a) shows the modeled photogenerated current versus thickness for the as-grown and annealed $\mathrm{Cu}_{2} \mathrm{O}$ layer under $\mathrm{AM} 1.5 \mathrm{G}$ illumination. The calculation shows that an annealed $\mathrm{Cu}_{2} \mathrm{O}$ layer of $2 \mu \mathrm{m}$ thickness will yield about $10 \mathrm{~mA} / \mathrm{cm} 2$ of photocurrent. This corresponds to approximately $80 \%$ of the photocurrent that can be generated for an infinitely thick $\mathrm{Cu}_{2} \mathrm{O}$ layer. Figure 4(a) also shows that the photo generated current is lower for the annealed $\mathrm{Cu}_{2} \mathrm{O}$ layer, when compared to the as-grown $\mathrm{Cu}_{2} \mathrm{O}$ layer, because there is less grain-boundary scattering present. In general, annealing is required to enhance the electrical properties of the sputter-deposited $\mathrm{Cu}_{2} \mathrm{O}$ absorber layer [12]. Figure 4(b) shows the calculated normalized reflectance, absorptance, and transmittance as a function of wavelength, using ray tracing method and the OPAL2 simulation platform [13]. In the modeled structure, an $80 \mathrm{~nm}$ thick front AZO layer, a $2 \mu \mathrm{m}$ thick $\mathrm{Cu}_{2} \mathrm{O}$ layer, and a $75 \mathrm{~nm}$ thick bottom $\mathrm{AZO}$ layer were implemented. 


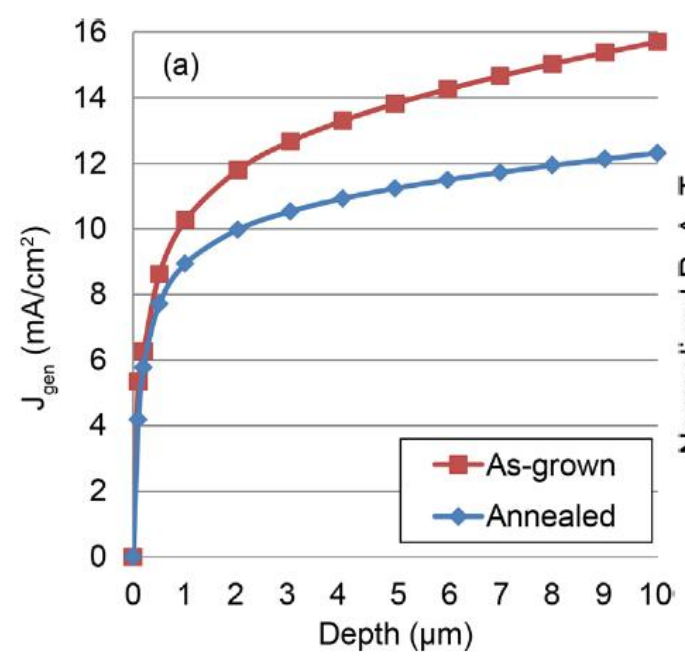

(a)

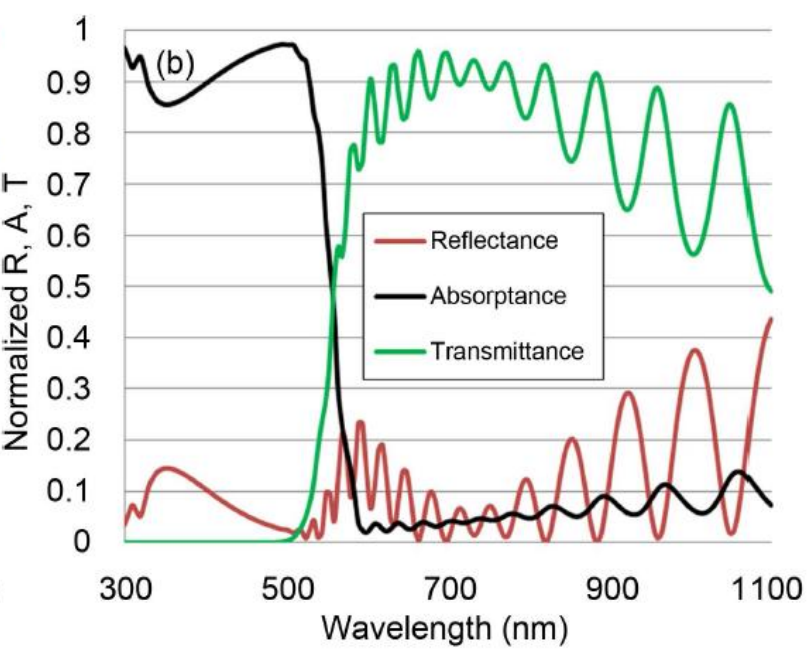

(b)

Fig. 4. (a) Photogenerated current as function of depth for the $\mathrm{Cu}_{2} \mathrm{O}$ absorber layer; (b) Normalized spectral reflectance $(\mathrm{R})$, absorptance $(\mathrm{A})$, and transmittance $(\mathrm{T})$ for the $\mathrm{ZnO} / \mathrm{Cu}_{2} \mathrm{O}$ subcell [1].

The usual thickness of a $\mathrm{SiN}_{\mathrm{x}}$ anti-reflection coating in a conventional c-Si solar cell is around $80 \mathrm{~nm}$. Despite that, in a STHSC device the energy spectrum of photons going towards the c-Si bottom subcell is different compared to a conventional cell, since most short-wavelength photons are absorbed in the top subcell. Figure 5a shows the transmitted and absorbed spectral intensity for the $\mathrm{ZnO} / \mathrm{Cu}_{2} \mathrm{O}$ subcell. In order to allow the $\mathrm{SiN}_{\mathrm{x}}$ layer to act as an effective antireflection coating, its thickness has to be increased to accommodate the photon spectrum shift towards longer wavelengths. The percentage of reflectance, absorptance, and transmittance in average, as a function of thickness for the $\mathrm{SiN}_{\mathrm{x}}$ layer are depicted in Figure 5b. The simulation shows that the lowest reflectance and highest transmittance are obtained for around $120 \mathrm{~nm}$ thickness of the $\mathrm{SiN}_{\mathrm{x}}$ layer. Increasing the thickness of the $\mathrm{SiN}_{\mathrm{x}}$ layer from $80 \mathrm{~nm}$ to $120 \mathrm{~nm}$, reduces total reflectance for the STHSC device from $12.7 \%$ to $9.7 \%$.

A transfer matrix algorithm was implemented in MATLAB, for different buffer layer materials presented in Table 1 , specifically $\mathrm{ZnO}$, in order to analyze the absorptance and reflectance for the buffer layer (Figure 6a), respectively for the top $\mathrm{ZnO} / \mathrm{Cu}_{2} \mathrm{O}$ subcell (Figure 6b). The simulation presented in Figure 6a shows good absorptance in the upper range of the spectrum and low reflectance for the $\mathrm{ZnO}$ buffer layer. The algorithm was further applied to the metal oxide subcell, with the $\mathrm{ZnO}$ buffer layer implemented, in order to assess optical performance of the $\mathrm{ZnO} / \mathrm{Cu}_{2} \mathrm{O}$ heterojunction, as can be seen in Figure $6 \mathrm{~b}$. The optical performance is good, with over $80 \%$ absorptance in the visible spectrum range while the 
reflectance of the $\mathrm{Cu}_{2} \mathrm{O}$ layer is low, in agreement with the literature $[14,15]$. The peaks in the spectra can also be caused by material surface imperfections.

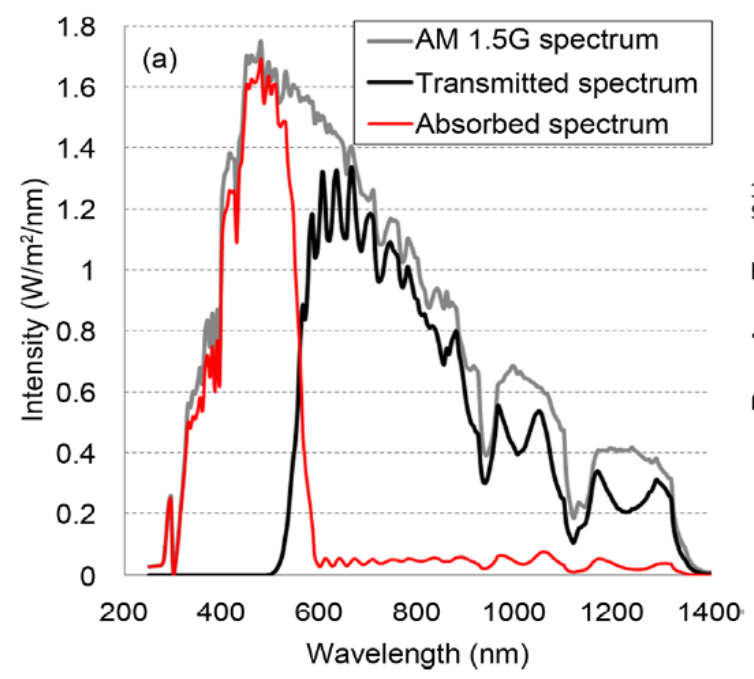

(a)

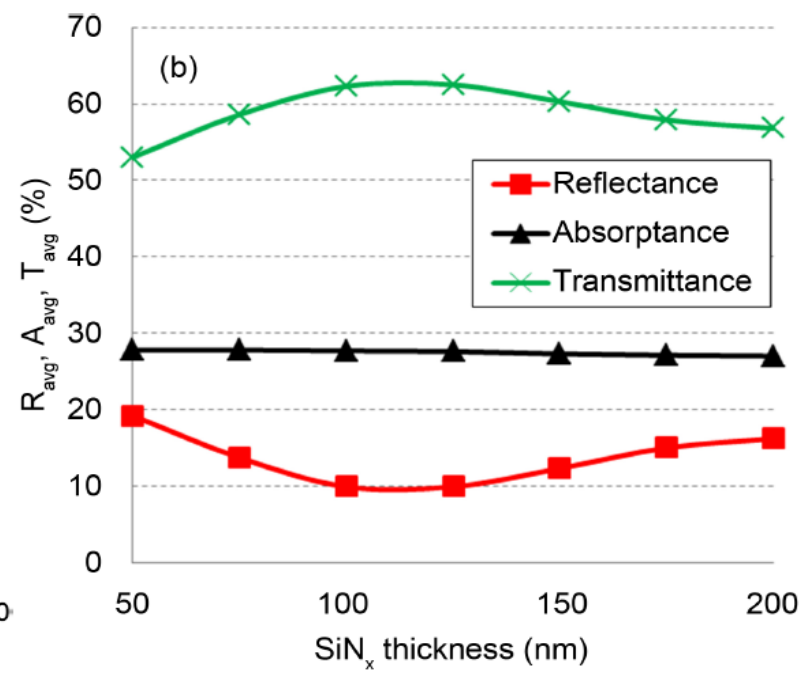

(b)

Fig. 5. (a) Absorbed and transmitted spectral intensity for the $\mathrm{ZnO} / \mathrm{Cu}_{2} \mathrm{O}$ subcell; (b) Average reflectance $\left(\mathrm{R}_{\mathrm{avg}}\right)$, absorptance $\left(\mathrm{A}_{\mathrm{avg}}\right)$, and transmittance $\left(\mathrm{T}_{\mathrm{avg}}\right)$ as a function of thickness for the $\mathrm{SiN}_{\mathrm{x}}$ layer [1].

Table 1. Buffer materials implemented in the simulation [9].

\begin{tabular}{llll}
\hline Buffer material & Aff. (eV) & Eg (eV) & Eff $(\%)$ \\
\hline $\mathrm{ZnO}$ & 3.6 & 3.35 & 11.91 \\
$\mathrm{TiO}_{2}$ & 3.9 & 3.44 & 8.26 \\
$\mathrm{Ga}_{2} \mathrm{O}_{3}$ & 4 & 5.18 & 8.92 \\
$\mathrm{CdS}$ & 4 & 2.40 & 8.45 \\
$\mathrm{Zn}\left(\mathrm{O}_{0.25}, \mathrm{~S}_{0.75}\right)$ & 4.07 & 3.13 & 6.23 \\
$\mathrm{Zn}\left(\mathrm{O}_{0.5}, \mathrm{~S}_{0.5}\right)$ & 4.45 & 2.83 & 2.8 \\
$\mathrm{Zn}\left(\mathrm{O}_{0.75}, \mathrm{~S}_{0.25}\right)$ & 4.58 & 2.97 & 1.73 \\
$\mathrm{ZnS}$ & 4.5 & 3.50 & 3.97 \\
\hline
\end{tabular}
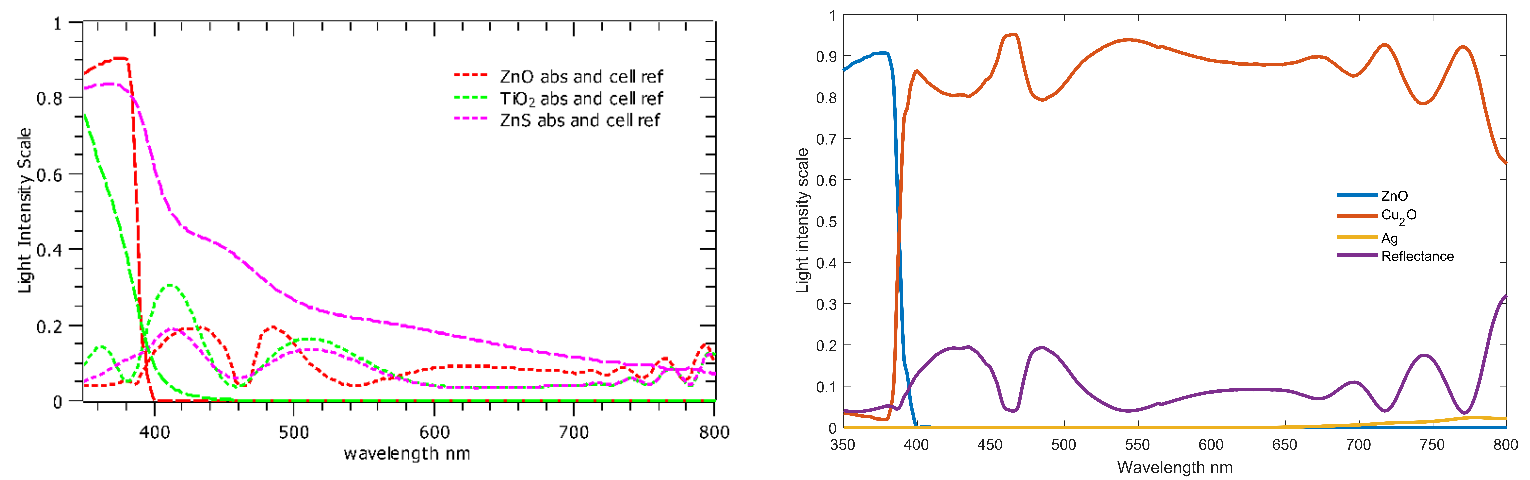

Figure 6. a) Buffer material absorptance and reflectance; b) Metal oxide top subcell absorptance and reflectance [10]. 
The modeling of the $\mathrm{ZnO} / \mathrm{Cu}_{2} \mathrm{O}$ subcell using Silvaco Atlas suggests that materials such as $\mathrm{Zn}(\mathrm{O}, \mathrm{S}), \mathrm{TiO}_{2}$, and $\mathrm{Ga}_{2} \mathrm{O}_{3}$ can be successfully implemented as buffer layer $[16,17]$, while providing a low conduction band offset for the heterojunction, shown in Table 1.

\section{Conclusions}

This review highlights the importance of using optical modeling and simulation tools for determining the optimum design for a silicon-based tandem heterojunction solar cell incorporating metal oxides $[1,4,5,9,10,14,18]$.

Basic methods for optical modeling, namely ray tracing and transfer matrix algorithms, were applied.

Using several specialized simulation software, the optical spectral characteristics (reflectance, absorptance and transmittance) of the absorber, buffer and AZO layers, were determined and used to find the optimum layer thicknesses.

\section{Acknowledgements}

This work was conducted under: (1) the research project SOLHET, 2016-2019, MERA.Net program, supported by the Research Council of Norway (RCN), project no. 251789 and the Romanian Executive Agency for Higher Education, Research, Development and Innovation Funding (UEFISCDI), project no. 34/2016; (2) the project MultiscaleSolar MP1406, 2015-2019, supported by the European Commission through COST program.

\section{References}

[1] Ø. Nordseth, R. Kumar, K. Bergum, L. Fara, S. E. Foss, H. Haug, F. Dragan, D. Craciunescu, P. Sterian, I. Chilibon, C. Vasiliu, L. Baschir, D. Savastru, E. Monakhov, B. G. Svensson. Optical Analysis of a $\mathrm{ZnO} / \mathrm{Cu}_{2} \mathrm{O}$ Subcell in a Silicon-Based Tandem Heterojunction Solar Cell, Green and Sustainable Chemistry 7 (2017) 57-69

[2] L. Fara, A. Diaconu, F. Dragan. Trends, Challenges and Opportunities in Advanced Solar Cells Technologies and PV Market, Journal of Green Engineering 5 (2016) 157-186

[3] Y. Takiguchi, S. Miyajima. Device simulation of cuprous oxide heterojunction solar cells, Jpn. J. Appl. Phys. 54 (2015) 112303

[4] R. Mitroi, V. Ninulescu, L. Fara. Tandem solar cells based on $\mathrm{Cu}_{2} \mathrm{O}$ and c-Si subcells in parallel configuration: numerical simulation, International Journal of Photoenergy 2017 (2017) 7284367 
[5] R. Mitroi, V. Ninulescu, L. Fara. Performance optimization of solar cells based on heterojunctions with $\mathrm{Cu}_{2} \mathrm{O}$ : numerical analysis. Journal of Energy Engineering 143(4) (2017) 04017005

[6] L. Fara, M. Yamaguchi. Advanced Solar Cell Materials, Technology, Modeling, and Simulation. IGI Global Publishing House, Hershey (2013).

[7] B. G. Svensson, S. J. Pearton, C. Jagadish. Oxide Semiconductors, Semiconductors and Semimetals. Elsevier \& Academic Press, Amsterdam, 88 (2013)

[8] F. Dragan, L. Fara, P. Sterian, D. Craciunescu, C. Dumitru. Colored building integrated photovoltaic systems based on DSSC and metal oxides solar cells, Proceedings of the National Symposium on Energy and Environment in Contemporary Context, UAUIM Publishing House (2017)

[9] Ø. Nordseth, R. Kumar, K. Bergum, L. Fara, S. E. Foss, H. Haug, C. Dumitru, V. Muscurel, F. Dragan, D. Craciunescu, P. Sterian, I. Chilibon, C. Vasiliu, L. Baschir, D. Savastru, E. Monakhov, B. G. Svensson. Electro-Optical Modeling of a $\mathrm{ZnO} / \mathrm{Cu}_{2} \mathrm{O}$ Subcell in a Silicon-Based Tandem Heterojunction Solar Cell. Proceedings of the 33rd European Photovoltaic Solar Energy Conference and Exhibition, session 1CV.3.85, (2017) $172-177$

[10] C. Dumitru, V. Muscurel, Ø. Nordseth, L. Fara, P. Sterian. Optimization of ElectroOptical Performance and Material Parameters for a Tandem Metal Oxide Solar Cell, Proceedings of ICCSA 2018 (2018) (to be published)

[11] ATLAS User's Manual - Device Simulation Software, Silvaco, Santa Clara, USA, (2016)

[12] Ø. Nordseth, I. Chilibon, B. G. Svensson, R. Kumar, S. E. Foss, C. Vasiliu, R. Iordanescu, L. Baschir, D. Savastru, L. Fara, R. Ghita. Characterization of copper oxide photosensitive thin films, Proceedings of the ROCAM 2017 Conference, 11-14 July 2017, Bucharest (2017) 86

[13] S. C. Baker-Finch, K. R. McIntosh. OPAL 2: Rapid Optical Simulation of Silicon Solar Cells. Proceedings of the 38th IEEE Photovoltaic Specialists Conference, Austin (2012) 265-271.

[14] C. Dumitru, V. Muscurel, Ø. Nordseth, L. Fara, P. Sterian. Electrical modeling of the buffer layer for a $\mathrm{Cu}_{2} \mathrm{O} / \mathrm{ZnO}$ solar cell using Silvaco Atlas, UPB. Scientific Bulletin Series B, 79(2) (2017) 173-178

[15] F. K. Mugwang'a, P. K. Karimi, W. K. Njoroge, O. Omayio, S. M. Waita. Optical characterization of Copper Oxide thin films prepared by reactive dc magnetron sputtering 
for solar cell applications, International Journal on Thin Film Science and Technology 2 (1) (2013) 15-24

[16] R. E. Brandt, M. Young, H. H. Park, A. Dameron, D. Chua, Y. S. Lee, G. Teeter, R. G. Gordon, T. Buonassisi. Band Offsets of N-Type Electron-Selective Contacts on Cuprous Oxide (Cu2O) for Photovoltaics, Applied Physics Letters 105 (2014) 263901.

[17] T. Minami, Y. Nishi, T. Miyata. High-efficiency Cu2O-based heterojunction solar cells fabricated using a $\mathrm{Ga}_{2} \mathrm{O}_{3}$ thin film as n-type layer, Applied Physics Express 6(4) (2013) 044101

[18] Ø. Nordseth, R. Kumar, K. Bergum, L. Fara, I. Chilibon, S. E. Foss, E. Monakhov, B. G. Svensson. Silicon-based tandem solar cells. Boosting the performance using non-toxic metal oxides, Laboratory Journal - Business Web for Users in Science and Industry (2017) 